\title{
A checklist of Bombyliidae (Diptera) from Mordovia, Russia and variation of wing shape in Bombylius species
}

\author{
MARIYA ALEXANDROVNA CHURSINA ${ }^{1, \boldsymbol{v}}$, ALEXANDER BORISOVICH RUCHIN ${ }^{2, v \bullet}$ \\ ${ }^{1}$ Voronezh State University. Universitetskaya sq., 1, 394006 Voronezh, Russia. "email: chursina.1988@list.ru \\ ${ }^{2}$ Joint Directorate of the Mordovia State Nature Reserve and National Park "Smolny". 431230 Republic of Mordovia, Temnikov District, Pushta \\ Settlement, Russia. "email: sasha_ruchin@rambler.ru
}

Manuscript received: 3 October 2018. Revision accepted: 1 November 2018.

\begin{abstract}
Chursina MA, Ruchin AB. 2018. A checklist of Bombyliidae (Diptera) from Mordovia, Russia and variation of wing shape in Bombylius species. Biodiversitas 19: 2147-2156. A checklist of Bombyliidae (Diptera) of Republic of Mordovia (Russia) is provided, based on material collected from 2008 to 2017 . One hundred ninety specimens from 75 localities were collected. Fourteen of the twenty species are listed as belonging to the fauna for the first time. Intraspecific variation and sexual dimorphism in the wing shape of three species of the genus Bombylius Linnaeus, 1758 were investigated using geometric morphometric techniques. The analysis revealed that wing shape is a good discriminator of the species. In addition, significant sexual dimorphism were found: females of two of the three species had larger wings than males. The sex shape differences consisted mainly of changes in the placement of the $C u A$ and $A$ l, while interspecific wing shape variation distributed in more dimensions. There was no evidence for allometric relationships relating to sexual dimorphism and interspecific variation. Potential adaptive significance of interspecific and intersex variation in wing size and shape is discussed.
\end{abstract}

Keywords: Bombyliidae, Bombylius, geometric morphometrics, new records, Mordovia

\section{INTRODUCTION}

Biodiversity is an underestimated resource of the country and provides a vast range of environmental function. A review of biodiversity should be a major focus of basic biological researches (Vermeulen and Koziell 2002).

The Republic of Mordovia is located in the middle of Russian Plain. It characterized by forest and forest-steppe landscapes (Yamashkin 1998). Therefore, it is expected that region's biodiversity should be high enough. In the last decade as a result of invertebrate fauna inventory, 4000 species were found in the Republic Mordovia for the first time (Ruchin and Kurmaeva 2010; Mikhailov and Trushina 2013; Ruchin and Pilipenko 2015; Ruchin and Artaev 2016; Semenov 2016; Egorov and Shapovalov 2017; Ruchin and Makarkin 2017; Chursina and Ruchin 2018; Ruchin and Egorov 2018; Ruchin and Grishutkin 2018; Ruchin and Mikhailenko 2018; Tomaszewska et al. 2018). In doing so, some of these findings are rare species. These findings are of great interest for the researchers.

Data of the fauna of the family Bombyliidae is still limited despite wide distribution of species of the family and their important role in ecosystems. Species of Bombyliidae are worldwide in distribution; the family contains approximately 4600 described species (Evenhuis and Greathead 2003, 2015; Lamas and Evenhuis 2016). The larvae of bee flies are predators or ectoparasitoids of eggs and larvae (Boesi et al. 2008; Evenhuis 2017; Felicioli et al. 2017). Most of the immatures are parasitoids of solitary bees and wasps; several species (for example, Villa species) are endoparasitoids of moth larvae and pupae; species of the genus Hemipenthes Loew, 1869 are hyperparasitoids of other parasitoids that attack caterpillar and sawfly hosts. Some species are important natural enemies of major pests including locusts and grasshoppers, armyworms, slug and nettle caterpillars, and tsetse flies. For example, widespread species Hemipenthes morio (Linnaeus, 1758) attacks Tachinidae and Ichneumonidae (Yeates and Greathead 1997; Evenhuis and Greathead 2003).

Adults generally feed on nectar and pollen thus may play an important role in pollination of wild-flowers (Du Hull 1973; Negrobov et al. 2018). The fauna of bombyliid flies of several regions of Russia is insufficiently studied. The fauna of Yakutia contains 20 species from the three subfamilies (Nartshuk and Bagachanova 2012). The fauna in the Kirov region and Komi Republic includes 23 species (Pestov and Yuferev 2015) whereas the fauna of Samara region includes 41 species. A detailed research on bee flies from Caucasus has been carried out by Zaitzev (1966). In this regards, we believe that the bombyliid fauna of Republic of Mordovia merits further consideration.

Geometric morphometrics is a promising approach, aimed at a comparison of the shape. Wing shape has a particular importance for aerodynamic characteristics and can be particularly subject of evolutionary changes (Bonduriansky 2006; Francuski et al. 2009; Vujić et al. 2013; Nedeljković et al. 2015; Torres and MirandaEsquivel 2015). Variation in wing shape and size are currently used both for discriminant between morphologically cryptic taxa and describing evolutionarily 
transformation within a character system. A considerable number of studies have confirmed the importance of studies of shape variation for systematics and evolutionary biology (for example, Pepinelli et al. 2013). However, such study in the family Bombyliidae has not been conducted before.

Therefore, the first aim of this study is to contribute to the knowledge of bee fly fauna of the Republic of Mordovia. We have given brief notes on the distribution of each species. The second aim is to investigate the pattern of wing shape variation for the large and widespread genus Bombylius Linnaeus, 1758. For this purpose, we selected exemplars from three species: Bombylius discolor Mikan, 1796, Bombylius major Linnaeus, 1758, Bombilius minor Linnaeus, 1758.

\section{MATERIALS AND METHODS}

\section{Study area}

The Republic of Mordovia, Russia is located in the center of the East European Plain between $42^{\circ} 11^{\prime}$ and $46^{\circ} 45^{\prime}$ geographic longitude and $53^{\circ} 38^{\prime}$ and $55^{\circ} 11^{\prime}$ latitude, in the southwestern periphery of the Volga basin, between the Moksha and Sura rivers. The territory of republic situated in forest and forest-steppe quarters of Central Russia. The eastern part of Republic of Mordovia is located in the northwest of the Volga Upland and the western part in the Oka-Don lowland (Ruchin and Egorov 2017). Boreal coniferous and mixed forests are common in the west, north-west, and north of Mordovia Nature Reserve. Broad-leaved forests cover the central and eastern parts. In the east and south-east parts of the republic foreststeppe landscapes dominate (Yamashkin 1998).

Materials for this study were collected from various habitats in different localities of Mordovia State Nature Reserve in 2008, 2009 and 2011-2017 using individual hand net. More than 190 specimens from 73 localities were studied (Figure 1). The coordinates of sites are given in Table 1.

The specimens were killed by ethyl acetate and later were installed on entomological pins. The identification of collected specimens was made using Levenhuk 3ST binocular microscope. For species identification, the taxonomic keys by Zaitsev (1969, 2004), Kits et al. (2008) were used. The material was deposited in the Collection of the Mordovia State Nature Reserve, Saransk.

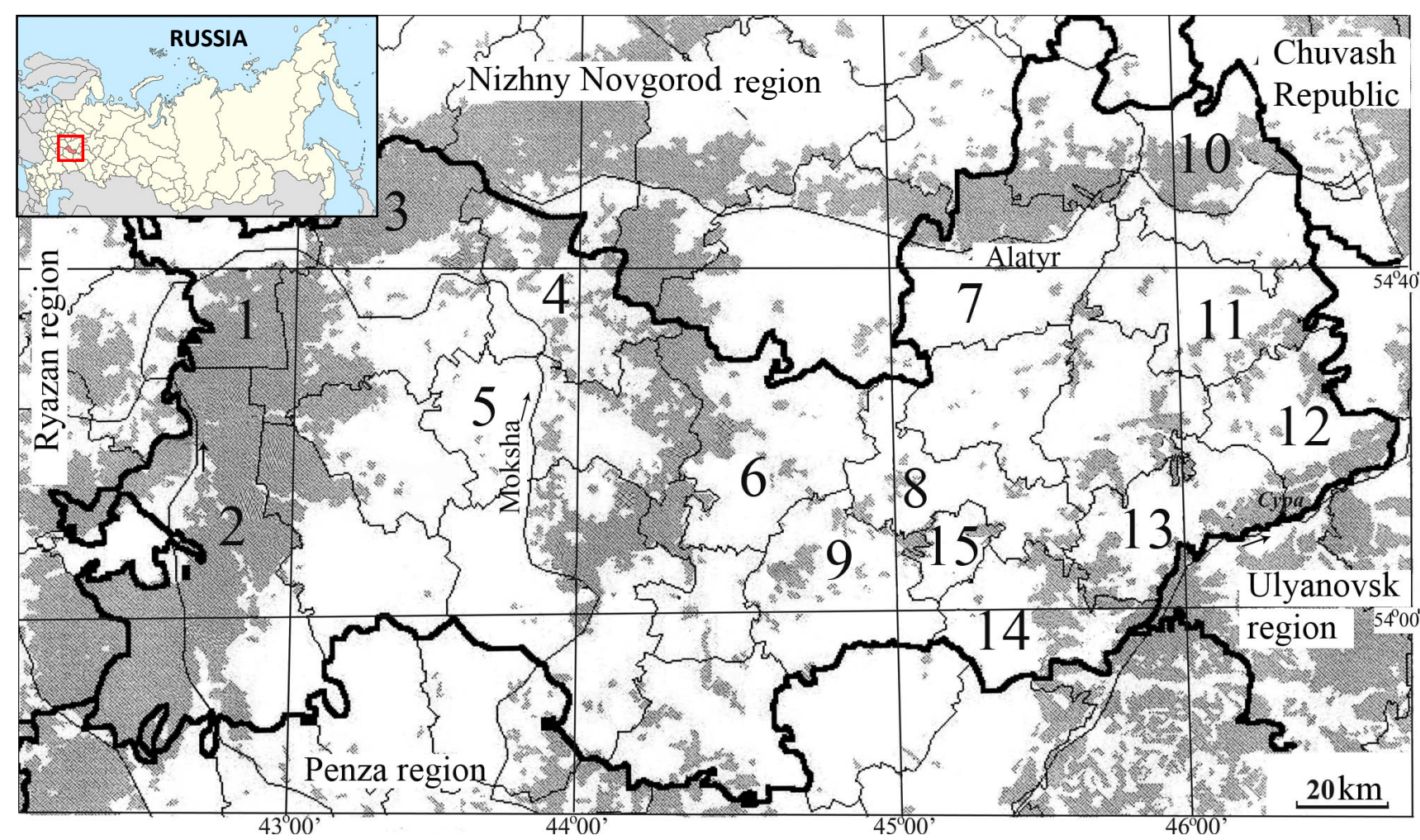

Figure 1. Location of the collecting sites in the Republic of Mordovia, Russia where the studied material was sampled: 1 . Tengushevo District, 2. Zubovo Polyana District, 3. Temnikov District, 4. Elniki District, 5. Krasnoslobodsk District, 6. Staroe Shaygovo District, 7. Ichalki District, 8. Lyambir District, 9. Ruzaevka District, 10. Ardatov District, 11. Atyashevo District, 12. Dubensky, 13. Bolshie Berezniki, 14. Kochkurovo District, 15. City district Saransk (see also Table 1). 
Table 1. Collecting sites and their coordinates in the Republic of Mordovia, Russia

\begin{tabular}{|c|c|c|c|}
\hline District & Collecting sites & Latitude & Longitude \\
\hline \multirow[t]{4}{*}{ Ardatov } & village Piksyasi & $54^{\circ} 39^{\prime} 32.3^{\prime \prime} \mathrm{N}$ & $\mathrm{J} 46^{\circ} 18^{\prime} 55.1 " \mathrm{E}$ \\
\hline & village Bolshoe Kuzmino & $54^{\circ} 57^{\prime} 00.3^{\prime \prime} \mathrm{N}$ & J $46^{\circ} 05^{\prime} 25.6^{\prime \prime} \mathrm{E}$ \\
\hline & village Probuzhdenie & $54^{\circ} 51^{\prime} 07.1^{\prime \prime} \mathrm{N}$ & J $46^{\circ} 07 ' 29.7 " \mathrm{E}$ \\
\hline & $\begin{array}{l}\text { village Mordovskaya } \\
\text { Kozlovka }\end{array}$ & $54^{\circ} 27^{\prime} 45.6^{\prime \prime} \mathrm{N}$ & J $43^{\circ} 18^{\prime} 37.5^{\prime \prime E}$ \\
\hline Bolshie & village Permisi & $54^{\circ} 5^{\prime} 45.3^{\prime \prime N}$ & $45^{\circ} 49^{\prime} 40.5^{\prime \prime} \mathrm{E}$ \\
\hline \multirow[t]{2}{*}{ Berezniki } & Simkino forestry & $54^{\circ} 15^{\prime} 29.9^{\prime \prime} \mathrm{N}$ & J $46^{\circ} 11^{\prime} 01.0 " \mathrm{E}$ \\
\hline & village Degilevka & $54^{\circ} 9^{\prime} 26.1^{\prime \prime} \mathrm{N}$ & $45^{\circ} 40^{\prime} 47.7^{\prime \prime E}$ \\
\hline \multirow[t]{2}{*}{ Dubensky } & village Krasnye Luga & $54^{\circ} 25^{\prime} 39.0^{\prime \prime} \mathrm{N}$ & J $46^{\circ} 23^{\prime} 20.0^{\prime \prime} \mathrm{E}$ \\
\hline & village Javleyka & $54^{\circ} 18^{\prime} 41.4^{\prime \prime} \mathrm{N}$ & J $46^{\circ} 26^{\prime} 01.6^{\prime \prime} \mathrm{E}$ \\
\hline \multirow[t]{3}{*}{ Elniki } & village Novye Shaly & $54^{\circ} 42^{\prime} 14.8^{\prime \prime} \mathrm{N}$ & J $43^{\circ} 37 ' 52.9^{\prime \prime E}$ \\
\hline & village Malye & $54^{\circ} 41^{\prime} 2.5^{\prime \prime} \mathrm{N}$ & $43^{\circ} 43^{\prime} 9.5^{\prime \prime} \mathrm{E}$ \\
\hline & Mordovskie Poshaty & & \\
\hline Ichalki & Barakhmanovo forestry & $54^{\circ} 45^{\prime} 51.2^{\prime \prime}$ & $45^{\circ} 24^{\prime} 03.0 " \mathrm{E}$ \\
\hline
\end{tabular}

Ichalki Barakhmanovo forestry, 5445'51.2"N 4524'03.0"E quarter 88

Barakhmanovo forestry, $54^{\circ} 45^{\prime} 43.9^{\prime \prime} \mathrm{N} 45^{\circ} 28^{\prime} 50.5^{\prime \prime} \mathrm{E}$ quarter 93

National Park

"Smolny",

Aleksandrovskoe

forestry

National Park

"Smolny", Lvovskoe

forestry, quarter 53

Kochkurovo village Muran

Krasnos- village Novaya Avgura

lobodsk village Selischi

village Sivin

village Sinyakovo

Lyambir village Atemar

Ruzaevka forest "Levzhenskij

sklon"

$3 \mathrm{~km} N$ village

Streleckaya Sloboda

village Levzhenskoe

village Russkoe

Baimakovo

City district city Saransk

Saransk village Gagarina

Staroe village Sarga

Shaygovo village Staroe Akshino

Temnikov, quarter 115

MSNR quarter 116

quarter 142

quarter 249

quarter 276

quarter 301

quarter 324

quarter 330

quarter 345

quarter 360

quarter 366

quarter 368

quarter 384

quarter 387

quarter 405

quarter 408

quarter 421

quarter 431

quarter 434

quarter 442

village Aksel

$54^{\circ} 02^{\prime} 34.5^{\prime \prime} \mathrm{N} 45^{\circ} 33^{\prime} 51.2^{\prime \prime} \mathrm{E}$

$54^{\circ} 19^{\prime} 43.7^{\prime \prime} \mathrm{N} 44^{\circ} 11^{\prime} 43.3^{\prime \prime} \mathrm{E}$ $54^{\circ} 27^{\prime} 39.3^{\prime \prime} \mathrm{N} 43^{\circ} 31^{\prime} 45.8^{\prime \prime} \mathrm{E}$ $54^{\circ} 21^{\prime} 18.2^{\prime \prime} \mathrm{N} 44^{\circ} 16^{\prime} 14.4^{\prime \prime} \mathrm{E}$ $54^{\circ} 25^{\prime} 20.6^{\prime \prime} \mathrm{N} 43^{\circ} 40^{\prime} 22.3^{\prime \prime} \mathrm{E}$ $54^{\circ} 11^{\prime} 3.1^{\prime \prime} \mathrm{N} \quad 45^{\circ} 23^{\prime} 51.0^{\prime \prime} \mathrm{E}$ $54^{\circ} 06^{\prime} 08.0^{\prime \prime} \mathrm{N} 45^{\circ} 06^{\prime} 04.5^{\prime \prime} \mathrm{E}$ $54^{\circ} 11^{\prime} 54.6^{\prime \prime} \mathrm{N} 44^{\circ} 42^{\prime} 16.4^{\prime \prime} \mathrm{E}$

$54^{\circ} 06^{\prime} 16.3^{\prime \prime} \mathrm{N} 45^{\circ} 04^{\prime} 01.5^{\prime \prime} \mathrm{E}$ $54^{\circ} 02 ' 27.9^{\prime \prime} \mathrm{N} 44^{\circ} 43^{\prime} 26.9^{\prime \prime} \mathrm{E}$

$54^{\circ} 10^{\prime} 41.7^{\prime \prime} \mathrm{N} 45^{\circ} 11^{\prime} 4.0^{\prime \prime} \mathrm{E}$ $54^{\circ} 11^{\prime} 06.5^{\prime \prime} \mathrm{N} 45^{\circ} 12^{\prime} 53.0^{\prime \prime} \mathrm{E}$ $54^{\circ} 22^{\prime} 07.7^{\prime \prime N} 44^{\circ} 30^{\prime} 44.6^{\prime \prime} \mathrm{E}$ $54^{\circ} 17^{\prime} 27.2^{\prime \prime} \mathrm{N} 44^{\circ} 42^{\prime} 55.8^{\prime \prime} \mathrm{E}$ $54^{\circ} 51^{\prime} 42.5^{\prime \prime} \mathrm{N} 43^{\circ} 09^{\prime} 49.2^{\prime \prime} \mathrm{E}$ $54^{\circ} 51^{\prime} 43.1^{\prime \prime} \mathrm{N} 43^{\circ} 10^{\prime} 37.7^{\prime \prime} \mathrm{E}$ $54^{\circ} 51^{\prime} 08.3^{\prime \prime} \mathrm{N} 43^{\circ} 09^{\prime} 47.0^{\prime \prime} \mathrm{E}$ $54^{\circ} 49^{\prime} 49.6^{\prime \prime} \mathrm{N} 43^{\circ} 32^{\prime} 30.4^{\prime \prime} \mathrm{E}$ $54^{\circ} 47^{\prime} 38.8^{\prime \prime} \mathrm{N} 43^{\circ} 10^{\prime} 46.1^{\prime \prime} \mathrm{E}$ $54^{\circ} 47^{\prime} 06.0^{\prime \prime} \mathrm{N} 43^{\circ} 10^{\prime} 47.6^{\prime \prime} \mathrm{E}$ $54^{\circ} 46^{\prime} 19.9^{\prime \prime} \mathrm{N} 43^{\circ} 05^{\prime} 48.5^{\prime \prime} \mathrm{E}$ $54^{\circ} 46^{\prime} 34.1^{\prime \prime} \mathrm{N} 43^{\circ} 11^{\prime} 52.3^{\prime \prime} \mathrm{E}$ $54^{\circ} 47^{\prime} 07.1^{\prime \prime} \mathrm{N} 43^{\circ} 19^{\prime} 41.3^{\prime \prime} \mathrm{E}$ $54^{\circ} 46^{\prime} 11.2^{\prime \prime} \mathrm{N} 43^{\circ} 13^{\prime} 43.4^{\prime \prime} \mathrm{E}$ $54^{\circ} 46^{\prime} 25.4^{\prime \prime} \mathrm{N} 43^{\circ} 20^{\prime} 02.4^{\prime \prime} \mathrm{E}$ $54^{\circ} 46^{\prime} 37.3^{\prime \prime} \mathrm{N} 43^{\circ} 22^{\prime} 08.7^{\prime \prime} \mathrm{E}$ $54^{\circ} 45^{\prime} 33.1^{\prime \prime} \mathrm{N} 43^{\circ} 12^{\prime} 44.5^{\prime \prime} \mathrm{E}$ $54^{\circ} 45^{\prime} 38.8^{\prime \prime} \mathrm{N} 43^{\circ} 16^{\prime} 05.8^{\prime \prime} \mathrm{E}$ $54^{\circ} 44^{\prime} 39.3^{\prime \prime} \mathrm{N} 43^{\circ} 09^{\prime} 07.5^{\prime \prime} \mathrm{E}$ $54^{\circ} 44^{\prime} 50.2^{\prime \prime} \mathrm{N} 43^{\circ} 12^{\prime} 16.5^{\prime \prime} \mathrm{E}$ $54^{\circ} 43^{\prime} 54.0^{\prime \prime} \mathrm{N} 43^{\circ} 07^{\prime} 33.6^{\prime \prime} \mathrm{E}$ $54^{\circ} 44^{\prime} 32.4^{\prime \prime} \mathrm{N} 43^{\circ} 17^{\prime} 00.7^{\prime \prime} \mathrm{E}$ $54^{\circ} 51^{\prime} 46.3^{\prime \prime} \mathrm{N} 43^{\circ} 09^{\prime} 02.2^{\prime \prime} \mathrm{E}$ $54^{\circ} 43^{\prime} 56.5^{\prime \prime} \mathrm{N} 43^{\circ} 15^{\prime} 02.1^{\prime \prime} \mathrm{E}$ $54^{\circ} 35^{\prime} 23.5^{\prime \prime} \mathrm{N} \mathrm{43} 24^{\prime} 13.3^{\prime \prime} \mathrm{E}$

\begin{tabular}{|c|c|c|}
\hline & village Alkaevo & $54^{\circ} 35^{\prime} 59.4^{\prime \prime} \mathrm{N} 43^{\circ} 20^{\prime} 52.3^{\prime \prime E}$ \\
\hline & village Andreevka & $54^{\circ} 37^{\prime} 56.4^{\prime \prime N} 43^{\circ} 19^{\prime} 09.8^{\prime \prime E}$ \\
\hline & village Veseliy & $54^{\circ} 32^{\prime} 52.5^{\prime \prime} \mathrm{N} 43^{\circ} 00^{\prime} 58.2^{\prime \prime} \mathrm{E}$ \\
\hline & village Kitsaevka & $54^{\circ} 36^{\prime} 46.8^{\prime \prime} \mathrm{N} 43^{\circ} 09^{\prime} 01.0^{\prime \prime} \mathrm{E}$ \\
\hline & village Lavrentevo & $54^{\circ} 29^{\prime} 27.0^{\prime \prime} \mathrm{N} 43^{\circ} 2^{\prime} 54.9^{\prime \prime} \mathrm{E}$ \\
\hline & village Purdoshki & $54^{\circ} 39^{\prime} 56.4^{\prime \prime} \mathrm{N} 43^{\circ} 34^{\prime} 23.5^{\prime \prime} \mathrm{E}$ \\
\hline & village Pushta & $54^{\circ} 43^{\prime} 07.1^{\prime \prime} \mathrm{N} 43^{\circ} 13^{\prime} 32.2^{\prime \prime} \mathrm{E}$ \\
\hline & $6 \mathrm{~km} \mathrm{NW}$ village Pushta & $54^{\circ} 44^{\prime} 15.3^{\prime \prime} \mathrm{N} 43^{\circ} 08^{\prime} 53.2^{\prime \prime} \mathrm{E}$ \\
\hline & village Tarkhany & $54^{\circ} 32^{\prime} 20.0^{\prime \prime} \mathrm{N} 43^{\circ} 24^{\prime} 34.3^{\prime \prime E}$ \\
\hline & village Tatarskoe & $54^{\circ} 41^{\prime} 45.8^{\prime \prime} \mathrm{N} 43^{\circ} 14^{\prime} 35.0^{\prime \prime} \mathrm{E}$ \\
\hline & $\begin{array}{l}\text { Karaevo } \\
\text { village Tretyakovo }\end{array}$ & $54^{\circ} 31^{\prime} 55.2^{\prime \prime} \mathrm{N} 43^{\circ} 13^{\prime} 42.7^{\prime \prime E}$ \\
\hline & $14 \mathrm{~km}$ NNE village & 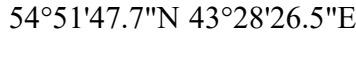 \\
\hline & $\begin{array}{l}\text { Pavlovka } \\
\text { cordon Inorsky }\end{array}$ & $54^{\circ} 43^{\prime} 36.3^{\prime \prime N} 43^{\circ} 09^{\prime} 22.6^{\prime \prime} \mathrm{E}$ \\
\hline & cordon Plotomoyka & $54^{\circ} 49^{\prime} 53.2^{\prime \prime} \mathrm{N} 43^{\circ} 8^{\prime} 17.0^{\prime \prime} \mathrm{E}$ \\
\hline & cordon Pavlovsky & $54^{\circ} 45^{\prime} 15.0^{\prime \prime} \mathrm{N} 43^{\circ} 24^{\prime} 27.6^{\prime \prime} \mathrm{E}$ \\
\hline & cordon Podrubnyj & $54^{\circ} 47^{\prime} 51.5^{\prime \prime} \mathrm{N} 43^{\circ} 08^{\prime} 48.4^{\prime \prime} \mathrm{E}$ \\
\hline & cordon Srednyaya & $54^{\circ} 54^{\prime} 09.4^{\prime \prime} \mathrm{N} 43^{\circ} 13^{\prime} 53.5^{\prime \prime} \mathrm{E}$ \\
\hline & $\begin{array}{l}\text { Melnitsa } \\
\text { cordon Steklyannyi }\end{array}$ & 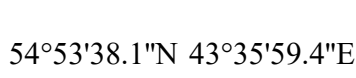 \\
\hline Tengushevo & village Barashevo & $54^{\circ} 31^{\prime} 43.5^{\prime \prime} \mathrm{N} 42^{\circ} 53^{\prime} 43.5^{\prime \prime} \mathrm{E}$ \\
\hline & village Klemeschei & $54^{\circ} 35^{\prime} 10.7^{\prime \prime} \mathrm{N} 42^{\circ} 51^{\prime} 39.0^{\prime \prime} \mathrm{E}$ \\
\hline Zubovo & $5 \mathrm{~km} \mathrm{SW}$ village & $54^{\circ} 26^{\prime} 26.6^{\prime \prime} \mathrm{N} \mathrm{42} 36^{\prime} 10.9 " \mathrm{E}$ \\
\hline Polyana & Bystrischi & \\
\hline & $8 \mathrm{~km} \mathrm{SW}$ village Vysha & $53^{\circ} 47^{\prime} 42.0^{\prime \prime} \mathrm{N} 42^{\circ} 18^{\prime} 43.9^{\prime \prime} \mathrm{E}$ \\
\hline & village Lesnoi & $54^{\circ} 27^{\prime} 49.0^{\prime \prime} \mathrm{N} 42^{\circ} 42^{\prime} 46.8^{\prime \prime} \mathrm{E}$ \\
\hline Atyashevo & village Selischi & $54^{\circ} 38^{\prime} 42.0^{\prime \prime} \mathrm{N} 46^{\circ} 15^{\prime} 36.0^{\prime \prime} \mathrm{E}$ \\
\hline
\end{tabular}

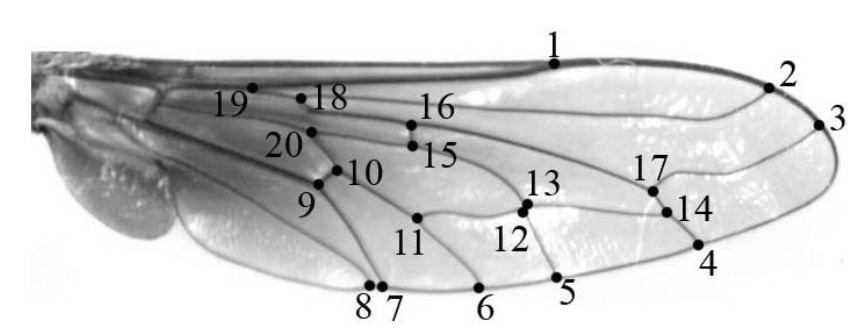

Figure 2. The wing of Bombylius minor (male) and positions of the landmarks used for studying wing shape (Temnikov District, MSNR, 10/V/2015)

\section{Data collection}

Wings of 106 specimens belonging to the genus were Bombylius were examined: Bombylius discolor (11 males and 12 females), Bombylius major (11 males and 38 females), Bombylius minor (14 males and 20 females). Wings of each fly were removed from body, mounted on a glass slide, and covered with a cover glass. The slides were photographed by means of a Levenhuk C NG microscopic camera (Levenhuk Inc., USA). Twenty homologous landmarks were used in order to describe wing shape (Figure 2). Configuration of landmarks was digitized using the software tpsDig (Rohlf 2003).

\section{Geometric and statistical analyses}

Then geometric morphometric analysis was performed. Firstly, a generalized Procrustes analysis was conducted in several steps: landmarks configurations were scaled to a unit of centroid size for eliminating the impact of variation in wing size, superimposed so that the centroid of each had 
coordinates $(0,0)$ and rotated so that the distance between landmarks of all specimens become minimal. A new set of variables (Procrustes residuals) contained the shape information and were used as shape data.

The centroid size of each wing was calculated to characterize an overall measure of wing. Statistical analyses of these sets of variables were performed using MorpholJ software (Klingenberg 2011) and Statistica 10 for Windows (StatSoft 2012). In order to prove evidence for the significant differences in wing centroid size and shape among the species and sexes, a one-way analysis of variance (ANOVA) was undertaken with Tukey post hoc test. A Procrustes ANOVA was used to test the effects of species, sex and side on wing shape. $\square$

Canonical variates analysis of Procrustes distances (CVA) and discriminant analysis (DA) was performed for the purpose to detect and describe the differences among species and sexes. Quantitative estimation of the differences was performed by calculating the Procrustes distances between the mean shape of males and females. The significance of differences was tested in a permutation test with 10000 replicates. $\square$

In order to consider the overall similarity of the sexual shape dimorphism of different species and shape changes attributing to sexual and interspecific variations, we used Mantel test of matrix correlation. The statistical significance of the results of Mantel test was assessed by the permutation test with 1000 replicates. In addition, for a more detailed investigation of the similarity of the sexual and interspecific patterns, we calculated the angle between the first principal component vectors and tested the null hypothesis stating that the PC vectors for different effects were identical. The allometric effects of interspecific wing variation and sexual dimorphism were estimated by regression analysis of shape variables on centroid size. $\square$

\section{RESULTS AND DISCUSSION}

A total of 20 species of Bombyliidae belonging 10 genera were recorded in the present work. Fourteen species including Anastoechus caucasicus Paramonov, 1930, A. nitidulus (Fabricius, 1794), Anthrax incomptus Walker, 1849, A. varius Fabricius, 1794, Bombylius ambustus Pallas, 1818, B. discolor Mikan, 1796, B. medius Linnaeus, 1758, B. minor Linnaeus, 1758, Bombylosoma nigriceps (Loew, 1862), B. unicolor (Loew, 1855), Exhyalanthrax afer (Fabricius, 1794), Hemipenthes morio (Linnaeus, 1758), Ogcodocera leucoprocta (Wiedemann, 1828), Thyridanthrax fenestratus (Fallen, 1814), Villa cingulum (Wiedemann in Meigen, 1820) are listed as new records for Mordovian bee fly fauna.

The world distribution is given for each species. Abbreviations used in the text include MSNR-Mordovia State Nature Reserve, PA-Palaearctic, OR-Oriental, NENearctic.

\section{Check-list}

Anastoechus caucasicus (Paramonov 1930). Material. 1 ㅇ: 55 (6/VII/2013).
Distribution. PA: Armenia, Azerbaijan, Georgia, Moldova, Ukraine (Evenhuis and Greathead 2015); Russia: North Caucasus (Paranomov 1940; Zaitzev 1966).

Anastoechus nitidulus (Fabricius 1794).

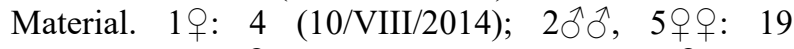
(20/VIII/2017); 1 우 $30 \quad$ (3/VIII/2014); 1 1 $: 31$

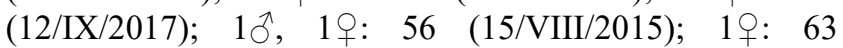
(4/VIII/2017); 1 đิ: 70 (18/VII/2015).

Distribution. PA: from Belgium through central Europe into European part of Russia, from Europe eastwards to Greece and further into Turkey and Iran; Kazakhstan, Kyrgyz Republic, Japan (Hasbenli and Evenhuis 2000; Evenhuis and Greathead 2015); Russia: from North Caucasus to South Siberia (Paranomov 1940; Zaitzev 1966, 2004), Yakutia (Nartshuk and Bagachanova 2012).

\section{Anthrax anthrax (Schrank 1781).}

Material. 1今, 1ㅇ: 33 (13/VIII/2015); 1ㅇ: 38 (20/VI/2015); $1 \delta^{\hat{1}}: 57$ (11/VII/2008) (Kurmaeva); $19: 58$ (9/VI/2013); 1q: 64 (3/VIII/2014).

Distribution. PA: from Spain, Italy, France eastwards through Central Europe into Ukraine, Russia, in Northern Europe (Falck and Greve 1999; Hasbenli and Evenhuis 2000; Evenhuis and Greathead 2003); Russia: European part of Russia to Leningrad region, North Caucasus, Crimea (Zaitzev 1966); Republic of Mordovia (Plavilshchikov 1964); Kirov region, Komi Republic (Pestov and Yuferev 2015), Yakutia (Nartshuk and Bagachanova 2012), Karelia (Polevoi 2006).

Anthrax incomptus Walker 1849.

Material. 1ठ, 1क: 63 (6/VIII/2017, 24/VIII/2017) (Semishin); 1ठో: 65 (7/VIII/2017) (Semishin); 1ठో: 66 (16/VII/2017).

Distribution. Australia; OR: Christmas I (Evenhuis and Greathead, 2003, 2015); PA: from Spain, Italy eastwards through Central Europe into European part of Russia (Evenhuis and Greathead 2003).

\section{Antrax varius Fabricius 1794.}

Material. 1: 63 (4/VIII/2017) (Semishin); 1 198 (12/VII/2014)

Distribution. Nearctic: USA (Evenhuis and Greathead 2015); PA: from Spain and Framce eastwards through Central Europe into Northern Europe, Ukraine and Russia; Turkey, Iran (Falck and Greve 1999; Hasbenli and Evenhuis 2000; Evenhuis and Greathead 2003, 2015); Russia: European part of Russia to Leningrad region, Crimea, North Caucasus (Zaitzev 1966); Kirov region, Komi Republic (Pestov and Yuferev 2015), Yakutia (Nartshuk and Bagachanova 2012), Karelia (Humala and Polevoi 2011).

\section{Bombylius ambustus Pallas 1818.}

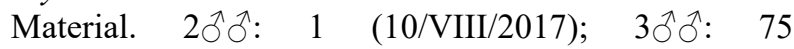
(10/VIII/2017).

Distribution. PA: from Spain and France eastwards through Central Europe into Ukraine and Russia; Turkey (Hasbenli and Evenhuis, 2000; Evenhuis and Greathead 
2003, 2015); Russia: from Ukrainian border further north into Voronezh and Kirov regions, to Siberia with the exception of the most northern parts, Primorsky territory (Paranomov 1940; Zaitzev 1966).

\section{Bombylius discolor Mikan 1796.}

Material. 1우: 21 (16/IV/2008) (Semishin); 1ð, $19: 22$

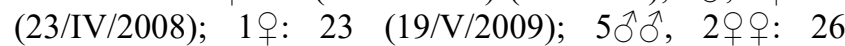
(8/IV/2008, 16/IV/2008, 21-22/IV/2008) (Semishin); $1 \overbrace{}^{\Uparrow}$

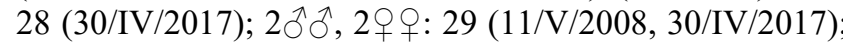
1 우 $65(7 / \mathrm{V} / 2013)$

Distribution. OR: China; PA: from Great Britain and France eastwards through Cetral Europe into Northern Europe, Ukraine and Russia; Turkish (Hasbenli and Evenhuis 2000; Evenhuis and Greathead 2003, 2015); Russia: Central and European part of Russia, North Caucasus (Paranomov 1940; Zaitzev 1966); Kirov region (Pestov and Yuferev 2015).

\section{Bombylius major Linnaeus 1758.}

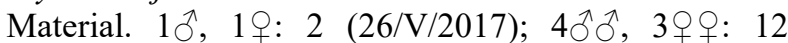
(9/IV/2008, 26/IV/2008, 01/V/2017;11/V/2013); 1 ふో: 14 (10/IV/2008); 3 우우 15 (26/IV/2008); 2 웅 25 (29/IV/2017); 2ิํํ, 2우: 26 (4/IV/2008, 12/V/2009,

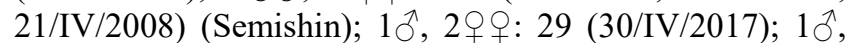

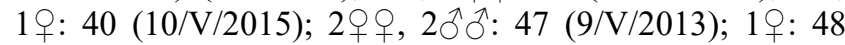
(6/V/2015); 2 우: 52 (11/V/2013); 3 우: 54 (12/V/2013); 4ふえ, 9 우: $58(10-11 / \mathrm{V} / 2015,27 / \mathrm{IV} / 2014,11 / \mathrm{V} / 2015$, 8/V/2013，30/IV/2013，3/V/2008，11-12/IV/2008); 4ふうે, 1ㅇ: 60 (16/IV/2017); 1 ㅇ: 71 (1/V/2008).

Distribution. OR: China, India, Pakistan, Thailand; Nearctic: Canada, USA; PA: from Northern Ireland, France and Spain eastwards through Central Europe and Northern Europe into Russia to Japan (Falck and Greve 1999; Evenhuis and Greathead 2003, 2015); Russia: from Leningrad region southward to Caucasus, North Caucasus (Paranomov 1940; Zaitzev 1966); Republic of Mordovia (Feoktistov 2011); Kirov region, Komi Republic (Pestov and Yuferev 2015), Yakutia (Nartshuk and Bagachanova 2012).

Bombylius medius Linnaeus 1758.

Material. 1ठิ: 22 (23/IV/2008); 1 đิ: 23 (19/V/2009);

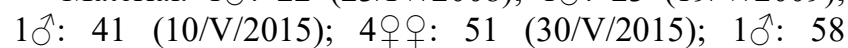
(11/V/2015); 1 q : 61 (17/V/2014).

Distribution. PA: from Spain and France eastwards through Central Europe into Russia; Iran, Iraq, Israel, Kuwait, Tajikistan (Falck and Greve 1999; Hasbenli and Evenhuis 2000; Evenhuis and Greathead, 2003, 2015); Russia: Central and European part of Russia, Siberia, North Caucasus (Paranomov 1940; Zaitzev 1966); Kirov region (Pestov and Yuferev 2015).

\section{Bombylius minor Linnaeus 1758}

Material. 1ठ: 1 (10/VIII/2017); $1 \delta^{\Uparrow}: 6$ (12/VIII/2017);

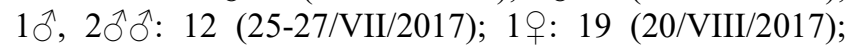
1ふ่, 1 ㅇ: 32 (11/VII/2015); $1 \delta^{\Uparrow}: 59$ (7/VII/2013).

Distribution. PA: from Spain, France and Great Britain eastwards through Central Europe and Northern Europe into Russia, Kazakhstan, Kyrgyz Republic, Mongolia
(Falck and Greve 1999; Hasbenli and Evenhuis 2000; Evenhuis and Greathead 2003, 2015); Russia: European part of Russia with the exception of the Far North, Leningrad region (Paranomov 1940; Zaitzev 1966); Kirov region, Komi Republic (Pestov and Yuferev 2015).

\section{Bombylosoma nigriceps (Loew 1862).}

Material. 1 $\delta^{\top}: 15$ (7/VII/2017).

Distribution. PA: from Spain and France eastwards through Austria, Bulgaria, Poland, Greece into European part of Russia; Turkey, Iran, Georgia (Hasbenli and Evenhuis 2000; Evenhuis and Greathead 2003, 2015); Russia: South part of European Russia including Crimea, Caucasus (Paranomov 1940; Zaitzev 1966); Republic of Mordovia (Plavilshchikov 1964); Kirov region, Komi Republic (Pestov and Yuferev 2015).

\section{Bombylosoma unicolor (Loew 1855).}

Material. 19: 4 (08/VI/2013).

Distribution. PA: from Spain and France eastwards through Italy, Hungary, Bulgaria, Moldova into Russia; Turkish, Greece, Armenia, Egypt, Tunisia (Hasbenli and Evenhuis 2000; Evenhuis and Greathead 2003, 2015); Russia: North Caucasus, Crimea (Paranomov 1940; Zaitzev 1966).

\section{Exoprosopa capucina (Fabricius 1781).}

Material. 1ㅇ: 66 (12/VI/2013).

Distribution. PA: from Spain and France eastwards through Central Europe and Northern Europe into Russia; Turkey, Turkmenistan, Uzbekistan (Evenhuis and Greathead 2003, 2015); Russia: European part of Russia (Zaitzev 1966); Republic of Mordovia (Plavilshchikov 1964); Kirov region, Komi Republic (Pestov and Yuferev 2015).

\section{Exhyalanthrax afer (Fabricius 1794).}

Material. 1ô, 1ㅇ: 13 (2/VIII/2017) (Semishin).

Distribution. Afrotropical: Chad, Kenya, Eritrea; PA: from Spain and France eastwards through Central Europe and Northern Europe into Russia; Turkey, Kazakhstan, PA part of China, United Arab Emirates (Evenhuis and Greathead 2003, 2015); Russia: European part of Russia to Leningrad region, North Caucasus (Zaitzev 1966); Yakutia (Nartshuk and Bagachanova 2012).

\section{Hemipenthes maura (Linnaeus 1758).}

Material. 1ठ: 3 (2/VII/2008); $1 \delta^{\lambda}: 15$ (21/VI/2008); $3 \widehat{\jmath}: 24$ (9-13/VI/2009); 1ڤ̂, 2 우: 26 (24-28/VI/2011, 9/VIII/2008) (Semishin); 1ํ: 30 (3/VIII/2014); 1ð̄: 41

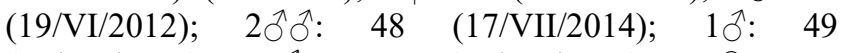
(16/VII/2015); 1 1ठ: $^{\lambda} 66$ (11/VII/2015); 19 : 68 (12/VII/2014).

Distribution. PA: from Spain and France eastwards through Central Europe and Northern Europe into Russia; Turkey, Tajikistan, PA part of China (Falck and Greve 1999; Hasbenli and Evenhuis 2000; Evenhuis and Greathead 2003, 2015); Russia: from Ukrainian border to North Caucasus, Ural and Siberia, Far East, Sakhalin Island (Zaitzev 1966); Republic of Mordovia (Feoktistov 2011); 
Kirov region, Komi Republic (Pestov and Yuferev 2015), Yakutia (Nartshuk and Bagachanova 2012).

\section{Hemipenthes morio (Linnaeus 1758).}

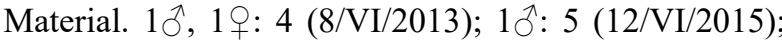

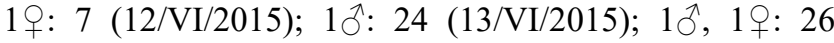
(24/VI/2011); $1 \overbrace{}^{\lambda: ~} 41$ (19/VI/2012); 19 : 45 (21/VI/2015);

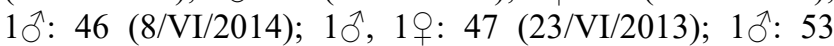

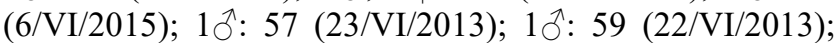
1ठ: 62 (17/VI/2013); 1 ऊ: 69 (30/VI/2013).

Distribution. Nearctic: Canada, USA; PA: from Spain and France eastwards through Central Europe and Northern Europe into Russia; Turkey, Kazakhstan, Armenia (Hasbenli and Evenhuis 2000; Evenhuis and Greathead 2003, 2015); Russia: in Russia it is the most common and widely distributed species, it is distributed to the north, the middle Urals, is found in Siberia and the Far East (Zaitzev 1966); Kirov region, Komi Republic (Pestov and Yuferev 2015).

\section{Systoechus ctenopterus (Mikan 1796)}

Material. 1 $\delta^{\lambda}: 8$ (11/VI/2017); $1 \widehat{\delta}^{\lambda}: 9$ (11/VI/2017);

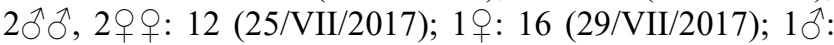
17 (20/VIII/2017).

Distribution. PA: from Spain and France eastwards through Central Europe and Northern Europe into Russia; Turkey, Egypt, Armenia (Hasbenli and Evenhuis 2000; Evenhuis and Greathead 2003, 2015); Russia: whole of Russia to Leningrad region in the north and to Yakutsk estward (Paranomov 1940; Zaitzev 1966); Republic of Mordovia (Plavilshchikov 1964; Feoktistov 2011); Kirov region, Komi Republic (Pestov and Yuferev 2015); Yakutia (Nartshuk and Bagachanova 2012).

\section{Thyridanthrax fenestratus (Fallen 1814).}

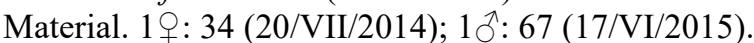

Distribution. PA: from Spain, France and Great Britain eastwards through Central Europe and Northern Europe into Russia; Turkey, Egypt, Azerbaijan, Armenia, Turkish (Falck and Greve 1999; Hasbenli and Evenhuis 2000; Evenhuis and Greathead 2003, 2015); Russia: Central part of Russia, North Caucasus (Zaitzev 1966); Kirov region, Komi Republic (Pestov and Yuferev 2015).

Villa cingulum (Wiedemann in Meigen 1820).

Material. 1ㅇ: 50 (15/VIII/2015).

Distribution. PA: Armenia, Azerbaijan, France, Greece, Georgia, Italy, Portugal, Spain, Yugoslavia (Evenhuis and Greathead 2003, 20015); Russia: The European part of Russia to Leningrad region, North Caucasus (Zaitzev 1966); Yakutia (Nartshuk and Bagachanova 2012).

\section{Villa hottentotta (Linnaeus 1758)}

Material. 1 ㅇ: 11 (19/VII/2015); 1 స̃: 18 (19/VII/2014);

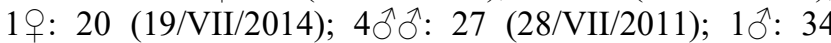
(20/VII/2014); $2 \hat{\jmath}: 35$ (11/VII/2015, 20/VII/2014); 1 웅

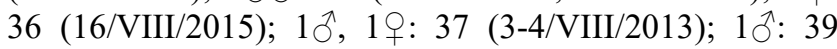
(27/VII/2014); 1 요 42 (27/VII/2014); 1 ㅇ 43

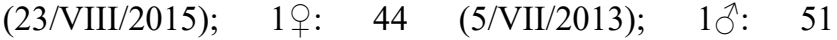
(15/VIII/2015); 1 q : 55 (6/VIII/2013); 1 : 58 (5/VII/2015); 1ठ઼: 72 (1/VIII/2009); $1 \delta^{\lambda}: 73$ (2/VIII/2015).

Distribution. PA: from Spain, France and Great Britain eastwards through Central Europe and Northern Europe into Russia; Turkey, Azerbaijan, Tunisia (Falck and Greve 1999; Hasbenli and Evenhuis 2000; Evenhuis and Greathead 2003, 2015); Russia: European part of Russia (Zaitzev 1966); Republic of Mordovia (Plavilshchikov 1964); Kirov region, Komi Republic (Pestov and Yuferev 2015), Yakutia (Nartshuk and Bagachanova 2012).

\section{Geometric morphometrics}

Highly significant differences in wing centroid size were observed among species $(\mathrm{F}=5.40, \mathrm{P}<0.01)$, but not between sexes $(\mathrm{F}=0.73, \mathrm{P}=0.40)$ (results of ANOVA). The Tukey post hoc test revealed that females of Bombylius major and $B$. discolor were significantly larger than males $(\mathrm{P}<0.1)$. For the species Bombylius minor, wing size did not vary significantly between sexes. The Procrustes ANOVA results also indicate that there were strong interspecific differences in wing shape $(\mathrm{F}=6.28, \mathrm{P}<$ $0.0001)$, as well as significant sexual dimorphism $(\mathrm{F}=$ $6.08, \mathrm{P}<0.0001)$. There were no significant differences in size and shape between left and right wings of studied specimens $(\mathrm{F}=1.12, \mathrm{P}=0.35$ and $\mathrm{F}=0.29, \mathrm{P}=1.0$ respectively).

Wing shape variation among species was analyzed using CVA, which resulted in two canonical variates. Most of the variance $(56.45 \%)$ for the Bombylius species comparison fell in the first canonical variate (CV1), which was associated with displacements of landmarks 2, 3, 7, 8, 12, 13, 14, 17, 18 and 19 (Figure 3). In other words, CV1 described a variation from a wing with landmarks 12 and 13 in a more distal position, 7 and 8 in a more proximal position and landmarks 2, 3, 14, 17, 18, 19 in a more anterior position (Bombylius discolor) to a wing with landmarks 12 and 13 in a more proximal position, 7 and 8 in a more distal position and landmarks 2, 3, 14, 17, 18, 19 in a more posterior position (Bombylius minor). From Figure 3 it can be seen that CV1 also revealed a clear separation of all three species. $\square$

The second canonical variate (CV2) accounted for approximately $43.55 \%$ of the overall wing shape variation, separated Bombylius major and B. minor from B. discolor. As shown by thin-plate splines, CV2 was associated with displacements of landmarks 1,4 and 5, i.e. CV2 reflects a variation from a wing with relatively distal apical points of $M_{1+} R_{5}$ and $M_{2}$ and relatively distal and posterior position of apical point of $R_{l}$ (Bombylius major) to a wing with relatively proximal apical points of $M_{1+} R_{5}$ and $M_{2}$ and relatively proximal and anterior position of apical point of $R_{I}$ (Bombylius minor and B. discolor).

DA successfully assigned almost all studied exemplars into their a priori species and sexes (Table 2). The percentage of correctly classified was about 99\%, which indicated wing shape is a reliable predictor of interspecific discrimination. 


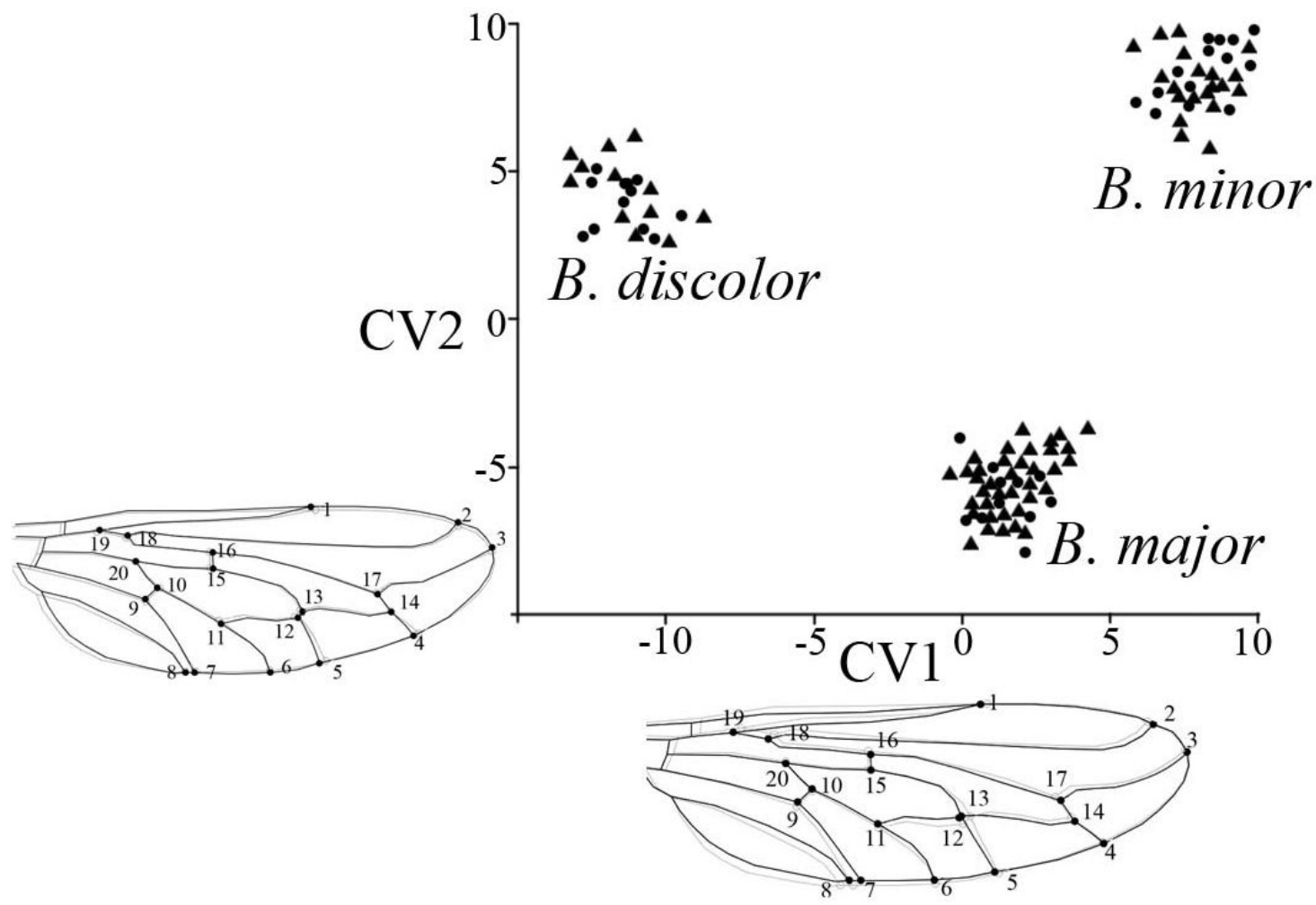

Figure 3. Scatter plot of individual scores from the CVA comparing specimens of the three Bombylius species with the associated shape changes (circles-males, triangles-females)

Table 2. Assignment of studied specimens to their a prori groups

\begin{tabular}{llccccccc}
\hline & $\mathbf{1}$ & $\mathbf{2}$ & $\mathbf{3}$ & $\mathbf{4}$ & $\mathbf{5}$ & $\mathbf{6}$ & $\begin{array}{c}\% \\
\text { correct }\end{array}$ \\
\hline 1 & B. discolor male & 11 & 0 & 0 & 0 & 0 & 0 & 100.00 \\
2 & B. discolor female & 0 & 12 & 0 & 0 & 0 & 0 & 100.00 \\
3 & B. major male & 0 & 0 & 11 & 0 & 0 & 0 & 100.00 \\
4 & B. major female & 0 & 0 & 0 & 37 & 0 & 0 & 100.00 \\
5 & B. minor male & 0 & 0 & 0 & 1 & 14 & 0 & 93.33 \\
6 & B. minor female & 0 & 0 & 0 & 0 & 0 & 20 & 100.00 \\
\hline Note: Rows: observed & classification; & \multicolumn{5}{c}{ columns-predicted } \\
classification
\end{tabular}

A general characteristic of sexual shape dimorphism in all three species is a narrowing of the region between $\mathrm{CuA}$ and $A_{1}$ (landmarks 7 and 8) (Figure 4). The trend toward displacement of branching point of vein $R_{2+3}$ and $R_{4}$ (landmark 18) have been revealed in Bombylius major and $B$. minor: landmark 18 is more distal in males than in females. In addition, sex-related variation in Bombylius major and $B$. minor involves a displacement of the point of intersection of $M_{3+4}$ and the wing margin (landmark 6): it is in a more proximal position in males than in females. The sex-related variation in Bombylius major and B. minor was distributed in few dimensions than in Bombylius discolor. The pattern of sexual dimorphism in the latest involved (except as stated above) displacements of landmarks 1, 4, $5,9,14$ and 17

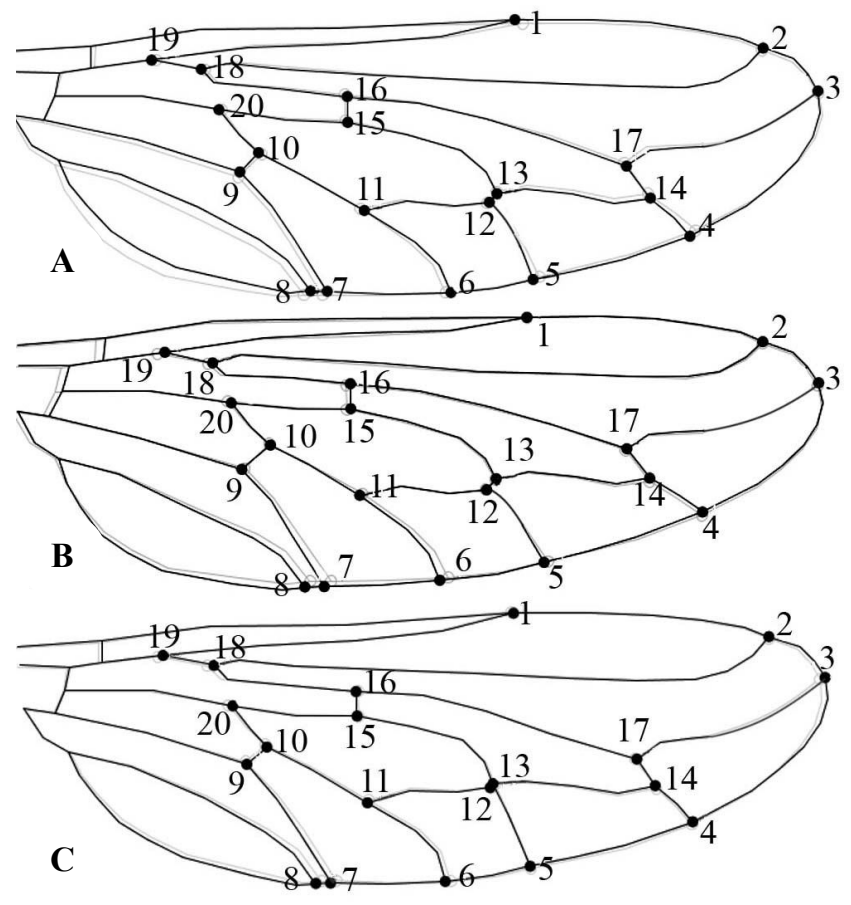

Figure 4. Changes in the wing shape associated with sexual dimorphism: the male average shape-black outlines, the female average shape-grey outlines. Species: A. Bombylius discolor, B. Bombylius major, C. Bombylius minor. 
Pairwise Procrustes distances among sexes ranged from 0.0415 in Bombylius minor to 0.0853 in Bombylius major. Permutation tests showed the differences to be significant $(\mathrm{P}<0.0001)$. The $\mathrm{PC} 1$ of wing shape sexual dimorphism in Bombylius major was similar from both the PC1 of $B$. discolor $\left(39.82^{\circ}, \mathrm{P}<0.0001\right)$ and Bombylius minor $\left(40.00^{\circ}, \mathrm{P}<0.0001\right)$. Similarity of sexual dimorphism in Bombylius major and B. discolor was confirmed by high matrix correlations between covariance matrices $(\mathrm{MC}=$ $0.61, \mathrm{P}<0.0001)$. However, we observed a low correlation between covariance matrices of sexual dimorphism of Bombylius major and B. minor $(\mathrm{MC}=0.14, \mathrm{P}=0.24)$ in one hand and Bombylius discolor and B. minor $(\mathrm{MC}=$ $0.22, \mathrm{P}=0.02$ ) on the other hand. The angle between the PC1 vectors of sex-related variation of Bombylius major and B. minor was $60.03^{\circ}(\mathrm{P}<0.0001)$.

The regression of shape variables on centroid size denied the occurrence of significant allometric effect of shape. Therefore, allometry explained $6.63 \%$ of interspecific variation. The allometric components of sexual dimorphism were 0.91\% (Bombylius discolor), $4.70 \%$ (Bombylius major) and $2.76 \%$ (Bombylius minor).

In Europe, approximately 335 species of the family Bombyliidae occur (Evenhuis and Greathead 2015). According to the numerous faunistic data (Hasbenli and Evenhuis 2000; Nartshuk and Bagachanova 2012; Kahanpää et al. 2014; Katona 2017), diversity of bee fly increases from north to south, and the most species occur in southern regions. $\square$

This paper is the first review of bee fly diversity of Republic of Mordovia. According to our data, fauna of the family Bombyliidae in Republic of Mordovia includes 21 species. In general, representatives of transpalaearctic group (Bombylius medius, Hemipenthes morio, Systoechus ctenopterus, Villa hottentotta) are the most prevalent.

Hemipenthes maura has been found at steppe meadow with motley-grass vegetation, this species visits bushes (Rosa cinnamomea, R. glabrifolia, R. rugosa). Systoechus ctenopterus has been found at dry meadow and meadowsteppe sites.

The first imago of bee flies appears in the Republic of Mordovia in April and May. In spring bombyliidae fauna is formed by the species of the genus Bombylius: B. discolor, $B$. major, B. medius. In the early summer the following species dominate: Anthrax anthrax, Bombylosoma unicolor, Exoprosopa capucina, Hemipenthes maura, $H$. morio, Thyridanthrax fenestratus and Systoechus ctenopterus. During July and August species Anastoechus nitidulus, Antrax varius, Villa hottentotta, Villa cingulum appear. In autumn species composition is poor and Anastoechus nitidulus remains. Bee flies preferred open space with grass vegetation; they are to be found on land, paths, and stones. $\square$

Unfortunately, it has not been possible to compare the biodiversity of bombyliid flies with neighboring regions due to the lack of comprehensive data on their fauna. Only in a number regions of Russia fauna of the family Bombyliidae is well-studied (Zaitzev 1966; Nartshuk and Bagachanova 2012; Pestov and Yuferev 2015).
The results of recent studies indicated that morphometric exploring wing shape variation represents an effective approach for finding differences between taxa and in examining of evolutionary transitions. Wing morphometric analysis produced interesting findings, for instance, of flies from the following families: Tabanidae (Torres and Miranda-Esquivel 2015), Tephritidae (Schutze et al 2012), Psychodidae (Dvorak et al. 2006) and Calliphoridae (Sontigun et al. 2017). These studies suggested that geometric morphometric analysis is a useful additional method for species discrimination, detection of differences between populations and sexes and consideration of evolutionary trends.

Results of our geometric morphometric analysis of bombyliid species suggested that wing shape is a good discriminator of the species. Although it is not necessary to use this fact directly, because these three bombyliid species differ in wing coloration, the number of visible morphological characters, however, the qualitative and quantitative characteristics of these differences can provide information about the adaptations and developmental pathway of species. Both interspecific variation and sexual dimorphism of wing shape were associated with displacement of distal point of $R_{l}$. The analysis revealed evolutionary trends in wing shape changes of Bombylius species. The first one represented displacement the terminus of $R_{l}$ toward the apical part of wing from Bombylius minor and B. discolor to B. major.

Sexual size and shape dimorphism is a widespread phenomenon in dipteral insects, and has therefore generated interest in evolutionary biology (Richard 1927; McLachlan 1986; Sivinski and Dorson 1992; Gidaszewski et al 2009). Sexual size and shape dimorphism is often the result of the different life strategies, roles in reproduction of males and females or adaptation of sexes to different ecological niches (Shine 1990) and in some cases carried a clear phylogenetic signal (Houle et al. 2003; Chursina and Negrobov 2018).

Our study has yield the presence of sexual size and shape dimorphism in the studied bombyliid species (sexual size dimorphism is absent in Bombylius discolor). However, at this stage behavior data of bee flies are fragmentary, therefore, the differences in wing size and shape between sexes it is possible to estimate only theoretically. Poulton (1918) noted that Bombylius males are able to change the note of his humming, which represents an element of courtship behavior. Perhaps there is an interaction between wing size and shape and sounds issuing by males. The resent studies (Panov 2007) of the gut content of Bombylius major clearly showed quantitative differences in the diets of males and females. Both males and females visit the same plants, but females consume considerably more pollen. Therefore, it may be preliminary assumed that the increases of wing size in female may be an adaptation resulting in increase of aerodynamic forces that are proportional to wing area (Elington 1984). However, this explanation of wing dimorphism requires providing conclusive evidence and broader survey of species in future studies. 
In addition, significant difference between $R_{l}$ length of males and females flies was found for all studied species. Females are about 3.8\% larger than males for $R_{l}$ length. Since the anterior wing margin experiences the greatest air resistance in flight, it can be concluded that there is a clear trend to 'costalization' of anterior veins, that may confer the improvement aerobatic ability of Bombylius flies. Similar trends were discovered in dolichopodid (Chursina and Negrobov 2018) and simuliids fly (Pepinelli 2013).

Finally, we tested allometric relationships both the species and sex level by considering association between wing shape variables and wing centroid size. It was revealed that shape variation for these species, for the most part, is not allometric. In addition, there was no evidence for allometric relationships relating to sexual dimorphism.

Our future research will be devoted primarily to the collection of morphometric data of other bombyliid species and enlarged samples to perform comparative analyses of the interspecific relationships and to reveal a presence of phylogenetic signal in the interspecific variation and sexual dimorphism of wing shape.

\section{REFERENCES}

Boesi R, Polidori C, Andrietti F. 2009. Searching for the right target: oviposition and feeding behavior in Bombylius bee flies (Diptera: Bombyliidae). Zool Stud 48: 141-150.

Bonduriansky R. 2006. Convergent evolution of sexual dimorphism in Diptera. J Morphol 267: 602-611

Chursina MA, Negrobov OP. 2018. Phylogenetic signal of wing shape in the Dolichopodinae subfamily (Diptera, Dolichopodidae). Ent Rev 98: 688-700.

Chursina MA, Ruchin AB. 2018. A checklist of Syrphidae (Diptera) from Mordovia, Russia. Halteres 9: 57-73. DOI: 10.5281/zenodo.1255874

Dvorak V, Aytekin AM, Alten B, Skarupova S, Vatypka J, Volf P. 2006 A comparison of the intraspecific variability of Phlebotomus sergenti Parrot, 1917 (Diptera: Psychodidae). J Vector Ecol 31: 229-238.

Du Hull FM. 1973. Bee flies of the world. The genera of the family Bombyliidae. Bull U S Natl Mus 286: 1-687.

Egorov LV, Shapovalov AM. 2017. On the distribution of a poorly known longicorn beetle, Phymatodes abietinus Plavilstshikov et Lurie, 1960 (Coleoptera, Cerambycidae: Cerambycinae). Ent Rev 97: 353-356.

Elington CP. 1984. The aerodynamics of hovering insect flight. III. Kinematics. Phil Trans R Soc Lond B 305: 41-78.

Evenhuis NL. 2017. A new species of Chrysanthrax Osten Sacken (Diptera: Bombyliidae) from Costa Rica parasitic on an ant lion (Neuroptera: Myrmeleontidae). Zootaxa 4363 (4): 583-588.

Evenhuis NL, Greathead DJ. 2003. World catalog of bee flies (Diptera: Bombyliidae): Corrigenda and Addenda. Zootaxa 300: 1-64.

Evenhuis NL, Greathead DJ. 2015. World catalog of bee flies (Diptera: Bombyliidae)

Revised. http://hbs.bishopmuseum.org/bombcat/bombcat-revised2015.pdf

Falck M, Greve L. 1999. The distribution of bee flies (Diptera, Bombyliidae), except the genus Villa, in Norway. Nor J Entomol 46: 89-109.

Felicioli A, Ambroselli S, Cilia G, Sagona S. 2017. Parasitization of a wild and reared population of the solitary bee Osmia cornuta Latr. by the parasitoid Anthrax anthrax Schrank (Diptera, Bombylidae) comparison between two types of artificial nest. J Apicultural Res 56 (5): 598-605. DOI: 10.1080/00218839.2017.1343019

Feoktistov VF. 2011. The list of insect species discovered for the firs time in the Mordovia State Nature Reserve and in adjacent territories. Mordovia Uni Bull 4: 83-89. [Russian]

Francuski L, Vujie A, Kovacevie A, Ludoski J, Milankov V. 2009 Identification of the species of the Cheilosia variabilis group (Diptera, Syrphidae) from the Balkan Penisula using wing geometric morphometrics, with the revision of status of C. melanopa redi Vujie, 1996. Contrib Zool 78: 129-140.

Gidaszewski NA, Baylac M, Klingenberg CP. 2009. Evolution of sexual dimorphism of wing shape in the Drosophila melanogaster subgroup. BMC Evol Biol 9: 110-121.

Hasbenli A, Evenhuis NL. 2000. Checklist of Turkish Bombyliidae (Diptera), with new records. J Entomol Res Soc 2: 25-43.

Houle D, Mezey JG, Galpern P, Carter A. 2003. Automated measurement of Drosophila wings. BMC Evol Biol 3: 1-13. DOI: 10.1186/14712148-3-25

Humala AE, Polevoi AV. 2011. Records of new and remarkable insect species (Insecta) in Northern Lagoda area. Trudy KarNC RAN 2: 142-144. [Russian]

Kahanpää J, Winqvist K, Zeegers Th. 2014. Checklist of the 'lower Brachycera' of Finland: Tabanomorpha, Asilomorpha and associated families (Diptera). ZooKeys 441: 165-181.

Katona P. 2017. New records of bee flies (Diptera: Bombyliidae) from Albania. Acta Zool Bulgar 69: 293-294.

Kits JH, Marshall SA, Evenhuis NL. 2008. The bee flies (Diptera: Bombyliidae) of Ontario, with a key to the species of eastern Canada. Can J Arthropod Identif 6: 1-52.

Klingenberg CP. 2011. MorphoJ: an integrated software package for geometric morphometrics. Mol Ecol Resour 11: 353-357.

Lamas CJE, Evenhuis NL. 2016. Family Bombyliidae. Zootaxa 4122 (1): 372-381. DOI: 10.11646/zootaxa.4122.1.31

McLachlan J. 1986. Sexual dimorphism in midges: strategies for flight in the rain-pool dweller Chironomus imicola (Diptera: Chironomidae). J Anim Ecol 55: 261-267.

Mikhailov KG, Trushina EE. 2013. On the spider fauna (Arachnida: Aranei) of the Mordovian State Reserve, Russia: preliminary results. Arthropoda Sel 22 (2): 189-196.

Nartshuk EP, Bagachanova AK. 2012. Fauna of parasitic bee flies (Diptera: Bombyliidae) of Yakutia (Russia). Caucas Entomol Bull 8: 293-299. [Russian]

Nedeljković Z, Ačanski J, Dan M, Obreht-Vidaković D, Ricarte A, Vujić A. 2015. An integrated approach to delimiting species borders in the genus Chrysotoxum Meigen, 1803 (Diptera: Syrphidae), with description of two new species. Contrib Zool 84: 285-304.

Negrobov OP, Maslova OO, Selivanova OV. 2018. Fauna of the family Dolichopodidae (Diptera) of the Astrakhan State Nature Biosphere Reserve (Russia). Nature Conservation Research 3 (Suppl. 2). DOI: $10.24189 /$ ncr.2018.055

Panov AA. 2007. Sex-related diet specificity in Bombylius major and some other Bombyliidae (Diptera). Ent Rev 87: 812-821.

Paranomov SY. 1940. Fam. Bombyliidae (subfam. Bombyliinae). Izd-vo AN SSSR, Moscow-Leningrad.

Pepinelli M, Spironello M, Currie DC. 2013. Geometric morphometrics as a tool for interpreting evolutionary transitions in the black fly wing (Diptera: Simuliidae). Zool J Linnean Soc 169: 377-388.

Pestov SV, Yuferev GI. 2015. To the fauna of bombyliid flies (Diptera, Bombyliidae) of Komi Republic and the Kirov Region. Bull Soc Imp Nat Mosc Otdel Biologii 120: 76-79.

Plavilshchikov NN. 1964. A list of insect species found on the territory of the Mordovian State Nature Reserve. Trudy MordovSNR 2: 105-134. [Russian]

Polevoi AV. 2006. New data on the dipteral fauna of Kivach nature reserve. Trudy KarNC RAN 10: 95-104.

Poulton EB. 1918. Capt. G. D. H. Carpenter's further notes in ex-German East Africa, almost exclusively East of Lake Tanganyika. Proc Ent Soc Lond 1918: 88-149.

Richard MA. 1927. Sexual selection and allied problems in the insects. Biol Rev 2: 298-364.

$\begin{array}{lllll}\text { Rohlf } & \text { FJ. } & 2003 . & \text { Tps-Dig } & \text { version }\end{array}$ https://tpsdig2.software.informer.com/ $\square$

Ruchin AB, Artaev ON. 2016. On expansion of the distribution range of some scoliid wasps (Scoliidae, Hymenoptera, Insecta) in the Middle Volga region. Res J Pharmaceut Biol Chem Sci 7 (3): 2110-2115.

Ruchin AB, Egorov LV. 2018. Fauna of longicorn beetles (Coleoptera: Cerambycidae) of Mordovia. Russian Entomol. J 27 (2): 161-177. doi: 10.15298/rusentj.27.2.07

Ruchin AB, Grishutkin GF. 2018. Biology and distribution of Parnassius apollo (Linnaeus, 1758) a rare species in Mordovia Republic, Russia. Biodiversitas 19 (2): 431-436. DOI:10.13057/biodiv/d190210

Ruchin AB, Kurmaeva DK. 2010. On rare insects of Mordovia included in the Red Book of the Russian Federation. Ent Rev 90: 712-717. DOI:10.1134/S0013873810060060 
Ruchin AB, Makarkin NV. 2017. Neuroptera and Raphidioptera in the Mordovia State Nature Reserve. Nature Conservation Research 2 (2) 38-46. doi: 10.24189/ncr.2017.001 [Russian]

Ruchin AB, Mikhailenko AP. 2018. Fauna of mantids and orthopterans (Insecta: Mantodea, Orthoptera) of the Mordovia State Nature Reserve, Russia. Biodiversitas 19 (4): 1194-1206. DOI: 10.13057/biodiv/d190403

Ruchin AB, Pilipenko VE. 2015. Preliminary checklist of the Tipuloidea (Diptera: Limoniidae, Tipulidae) of the Mordovia Republic. Eversmannia 41: 57-60. [Russian]

Semenov VB. 2016. New data on the fauna of Staphylinidae (Coleoptera) of Mordovia. Trudy MordovSNR 16: 431-434. [Russian]

Shine R. 1990. Ecological causes for the evolution of sexual dimorphism: a review of the evidence. Q Rev Biol 64: 419-461.

Schutze MK, Jessup A, Clarke AR. 2012. Wing shape as a potentia discriminator of morphologically similar pest taxa within the Bactocera dorsalis species complex (Diptera: Tephritidae). Bull Ent Res 102: 103-111.

Sivinski JM, Dorson G. 1992. Sexual dimorphism in Anastrepha suspense (Loew) and other tephritid fruit flies (Diptera: Tephritidae): Possible roles of developmental rate, fecundity, and dispersal. J Insect Behav 5: 491-506.

Sontigun N, Sukontason KL, Zajac BK, Zehner R, Sukontason K, Wannasan A, Amendt J. 2017. Wing morphometrics as a tool in species identification of forensically important blow flies of Thailand. Parasite Vector 10: 1-14.

StatSoft Inc. 2012. STATISTICA-data analysis software system. Ver. 12. [Computer software]. StatSoft, USA.
Tomaszewska W, Egorov LV, Ruchin AB, Vlasov DV. 2018. First record of Clemmus troglodytes (Coleoptera: Coccinelloidea, Anamorphidae) for the fauna of Russia. Nature Conserv Res 3 (3): 103-105.

Torres A, Miranda-Esquivel DR. 2015. Wing shape variation in the taxonomic recognition of species of Diachlorus Osten-Sacken (Diptera: Tabanidae) from Colombia. Neotrop Entomol 45: 180-191.

Vermeulen S, Koziell I. 2002. Integrating global and local values: a review of biodiversity assessment. International Institute for Environment and Development. London.

Vujić A, Ståhls G, Ačanski J, Bartsch H, Bygebjerg R, Stefanović A. 2013. Systematics of Pipizini and taxonomy of European Pipiza Fallen: molecular and morphological evidence (Diptera, Syrphidae). Zool Scripta 42: 288-305.

Yeates DK, Greathead D. 1997. The evolutionary pattern of host use in the Bombyliidae (Diptera): a diverse family of parasitoid flies. Biol J Linnean Soc 2: 149-185.

Yamashkin AA. 1998. Physical and geographical conditions of the Republic Mordovia. Publisher of the Mordovia State University, Saransk. [Russian]

Zaitzev VF. 1966. Parasitic flies of the family Bombyliidae (Diptera) in the fauna of Caucasus. Izd-vo of Academy of Sciences of the USSR, Leningrad.

Zaitsev VF. 1969. Family Bombyliidae. In: Bei-Bienko GYa (ed.). A key of insects of the European part of USSR. Vol. 2, Izd-vo "Nauka", Leningrad. [Russian]

Zaitzev VF. 2004. Family Bomyliidae. In: Ler PA (ed.). A key of insects of Russian Far East. Vol. 6. Part. 3. Dal'nauka, Vladivostok. [Russian] 